\title{
The Fate of Ochoa's School in the Origins of Oncogenetics in US (I)
}

\author{
Enrique Wulff-Barreiro \\ Marine Sciences Institute of Andalusia (CSIC), Cádiz, Spain \\ Email: enrique.wulff@icman.csic.es
}

Received 18 July 2014; revised 17 August 2014; accepted 16 September 2014

Copyright (C) 2014 by author and Scientific Research Publishing Inc.

This work is licensed under the Creative Commons Attribution International License (CC BY). http://creativecommons.org/licenses/by/4.0/

\section{(c) (i) Open Access}

\begin{abstract}
It was in the early eighties that a genuine school of spanish biochemists around Severo Ochoa participated in the oncogene races. Malignant cell transformation and oncogenes were put in relation during that era. Several prominent scientists coming from Spain have established and maintained a strong tradition of studies in the enzymology of retroviruses and transcriptional events. In this short historical account, we briefly pay tribute to these famous forerunners, by emphasizing both the originality and quality of their work, as well as the many accompanying conceptual and methodological analysis. We start with Àngel Pellicer (1948-) who, amongst other contributions, first established the landmark experimental transfection protocol and nucleated the onset of oncogenetics with his discovery that ras oncogenes were activated by mitogenic factors. Whereas Manuel Perucho (1948-) can be considered as one of the pioneers, if not the founder, of the cloning of human oncogene, through his experiments on H-ras, and he became a milestone in diagnostic detection to allow hospital technicians to screen for mutant ras genes. More known Mariano Barbacid (1949-) established that ras oncogene was a kind of common denominator for cancer, and clarified that their functional differences were by a single point mutation. In conclusion, this history demonstrates how eager spanish biochemists trained by Eladio Viñuela were to maintain the tradition of Severo Ochoa's long-standing scientific reputation in the US.
\end{abstract}

\section{Keywords}

Neoplasm, Molecular Cloning, Gamma-Rays, Point Mutation, Oncogenes, 3T3 Cells

\section{Introduction}

Recent books and publications dealing with the history of molecular biology and, in particular, with the search for the oncogene, have enriched our understanding of the history of cancer. While the ratio between cancer pre- 
vention and control [1], cancer treatments and national health policies [2], etiology and public health concerns [3], history of models of carcinogenesis [4], history of descriptive epidemiology [5], historical analysis of causality [6], or the emergence and development of new style of practices [7] have frequently been the centers of interest up to now. These contributions, added to the most recent congresses [8], suggest that the technology for studying genes and their patterns of expression are now advancing so fast that the molecular biologist will soon be telling the cancer epidemiologist what to look for [9].

It has been previously argued that few people question that Eladio Viñuela, along with Margarita Salas, have been not only the great promoters of molecular biology in Spain, but the key actors of this modest, although important renaissance that Spain enjoys nowadays in the field of biomedicine [10]. They successfully placed their research results in important and prestigious journals among other reasons, but above all, because they were abroad in centers directed by researchers who published a lot of papers and were much cited, and that is why they managed to get acknowledgment and funds for their projects. Indeed, the impact of the scientific papers and books published from 1931 by the spanish biochemist and Nobel laureate (1959) Severo Ochoa (19051993) who focused on a research career that he did not want to see affected by the social and political crisis of Spain [11], changed them drastically. Ochoa made sure that his Nobel speech appeared on the pages of Ciencia, the exiled Spanish Republicans journal published quarterly between 1940 and 1975 in Mexico [12] [13], and in what appears to be the result of mainly professional and economic reasons, in a family scale, he received this couple of married chemists in his laboratory at the New York University in 1963 (Figure 1). This local network further established strong contacts within Spain; they borrowed from other communities the elements of their own scientific ideology, which can be tentatively summarized as: "the pursuit of a hobby" (see in particular the work of Ochoa [14]). And in the seventies a complete generation of spanish scientists stayed at the US, where they enjoyed good consideration and facilities for research. It is the generation of Àngel Pellicer, Manuel Perucho and Mariano Barbacid, Eugenio Santos, Vicente Notario, José Antonio Melero, Bartolomé Cabrer, José López Carrascosa, Jesús Ávila and Vicente Larraga.
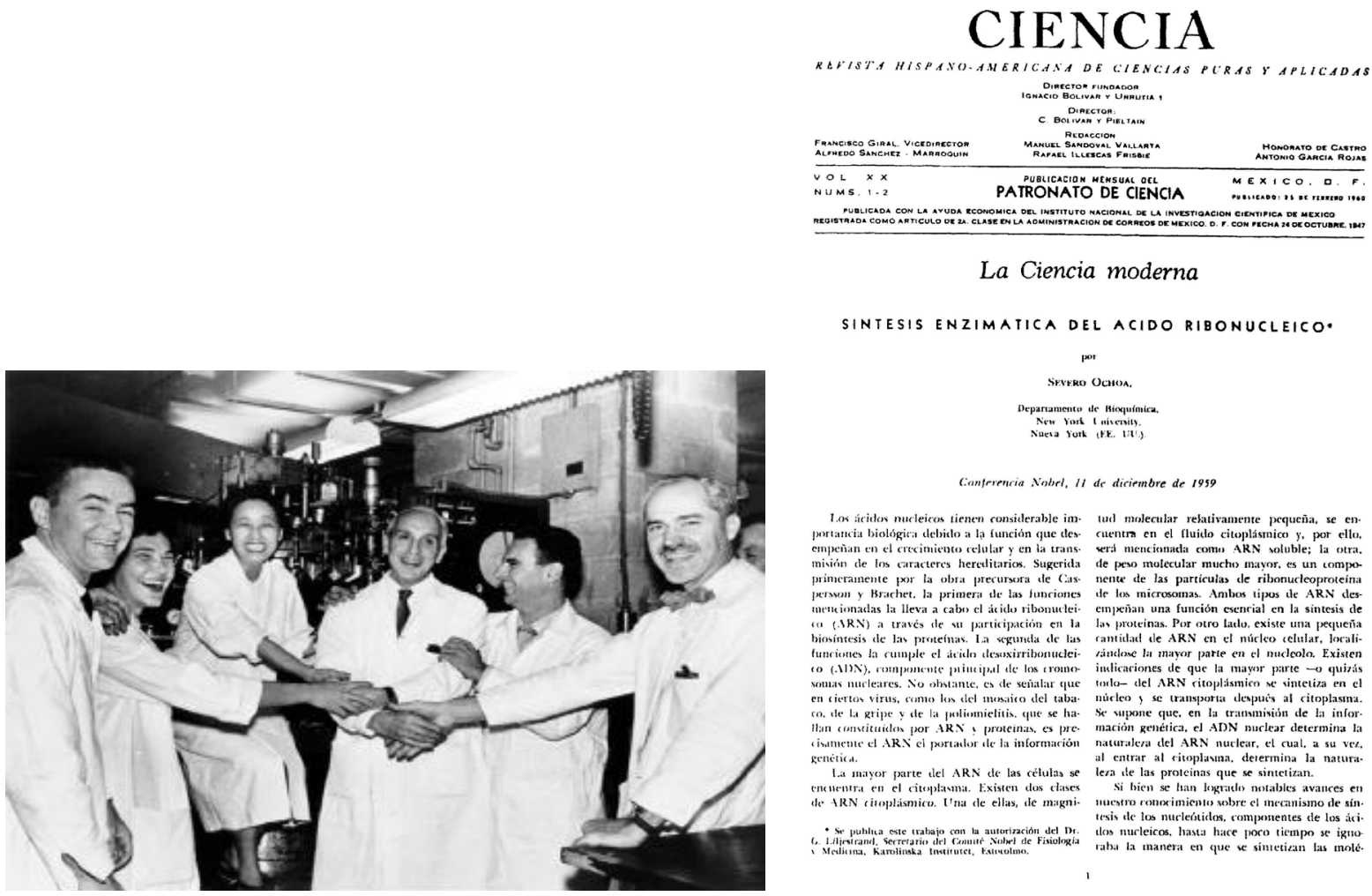

La Ciencia moderna
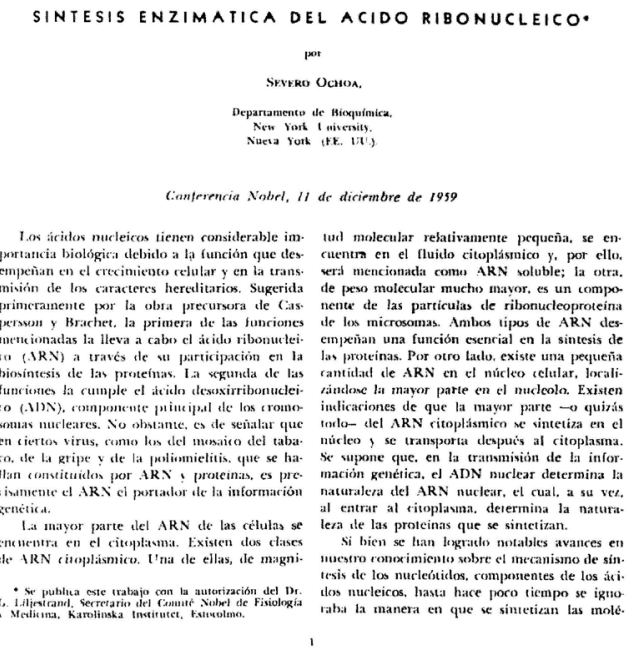

Figure 1. (Left) Professor Severo Ochoa is being congratulated by his team at New York University Biochemistry Department on his return from Stockholm where he received the 1959 Nobel Prize, for his work on the synthesis of RNA. (Right) Ochoa made sure that his Nobel speech appeared, in 1960, on the pages of the exiled Spanish Republicans journal published in México, Ciencia. 
A genuine "Ochoa School” of science is difficult to define because the difference in goals, functions and declining criteria pointed out both by Ochoa as originator of the scientific school and their researchers is largely determined by the diversity of the phenomenon and the variability of its content throughout the history of biochemical development. But once ras oncogene research obtained its most outstanding discoveries, these groups' results of researchers from Spain were shot by other groups which were able to publish before them. Because contrary to what might be thought, truth does not success as much as the ability of a number of individuals, or the force of some countries, to assert their own truth under their multiple relations with the medium that transmits and valuates it. Perucho, spanish scientist who made his thesis at the Biological Research Centre (CIB), in Madrid, has been left out in a discussed case of priority about a discovery on carcinogenicity. And his own generational colleagues, Barbacid and Pellicer, were overtaken in the Nobel for their work on the oncogenes as it was prematurely granted to other North American scientists for researches in this same field. Therefore, it is fair to say that, if not a school, a solid tradition in molecular biology was built up by many spanish scientists in the US around Ochoa. But even if it was bright and flourishing for over half a century, it really did not become a recognized part of the international scene of science. And on the verge of legitimation inside Spain the occurrence of their significant contributions appears as a national hidden curriculum [15].

In this short contribution, we would like to illustrate this tradition by presenting the observations and experiments performed in the field of oncogenetics which in its very initial stages were both carried out in the US, and by scientists from the school of Ochoa. This manuscript describes the characterization of a timeline for detailing the identification of Ras oncogenes. The first report that specifies in virtue of what property purified genes can be introduced in any kind of cultured cells came in 1978 from Àngel Pellicer's laboratory in the Columbia University [16]. In 1981, pioneering work from Perucho provided a powerful technique showing, for the first time, that a defined genetic element efficiently transformed NIH 3T3 cells [17]. And any doubts regarding the existence of transforming genes in human tumor cells was clarified in the spring 1982 by both the groups of Perucho and Barbacid [18] [19]. This is a great story, but how do historians judge it? This is a difficult question to answer as the history of science community appears to have made no, or at best very little, response to it. As Barbacid he says: "From the pioneering work with acute transforming retroviruses to the current post-genomic era, Ras genes have always been at the leading edge of signal transduction and molecular oncology" [20]. But if we start at the beginning, there are scholarly quibbles.

To begin with, one has to realize that the observation that activating mutations in the genes of the Ras family, which include $\mathrm{H}-, \mathrm{K}-$, and $\mathrm{N}$-ras, are oncogenic in experimental cell culture systems has been scarcely reviewed in professional history of science journals. On the contrary for the public at large the evidence that a mutation of ras was responsible for the tumor was a momentous problem from at least the medical research point of view. Thinking about the medical angle and its many contradictory theories via the contribution of oncogene scientists corresponds with the application of the tools and concepts of molecular biology to cancer [21]. But the proteins of the Ras family, function as key regulators of the signal transduction pathways controlling cell proliferation, survival, migration, and differentiation. And the history of the novel theories and facts brought to light by their discovery is like the phage work, that of a specific intellectual tradition which must be passed from person to person if that tradition is to persist. It is within a similar context that oncogenetics emerged and developed in Bethesda and Stony Brooks. If scientists efforts, via review articles, to realize the sequence of thought which other authors took in writing their accounts makes place to the history. What is there about molecular biologists' analysis that historians might emulate?

\section{2. Àngel Pellicer-A Remarkable Experimenter}

Three prominent scientists, at the origin of oncogenetics in US, made an impact on the future of molecular biology that paved the way to the awarding of the 1989 Nobel Prize: Àngel Pellicer (1948-), Manuel Perucho (1948-) and Mariano Barbacid (1949-). The three worked in the first efforts to clone an oncogene and contributed to ras genes research in a spectacular way. They set up the standard of scientific endeavor in molecular oncology for more than thirty years.

The work of Pellicer has been largely ignored by the historical narratives of the theories of oncogenesis, including Angier's early book [9], as well as modern historian and epistemiologist Michel Morange [22]. But his researches on the transference of genes mediated by DNA has permitted the study and isolation of several genes that confer to cells which possess them, a phenotypic property which allows to distinguish them from the re- 
maining cultured cells which do not own this property [23]-[25]. These results prove the usefulness of transfection assays as a means for the bioassay and isolation of restriction fragments carrying specific genetic information. From there mutation research swept up all in its path towards ras gene. Pellicer showed great interest in doing experiments and trying to convince others about his views. A very gifted experimenter he was also very inspired by the activation of ras oncogenes associated with the induction of tumors in experimental animals. Both his strong methodological instinct and his technical gifts were recognized by the father of modern immunology Michael Heidelberger, colleague of Ochoa himself at the Harvey Society. This latter author has emphasized a few remarkable methodological ideas proposed by Pellicer, who was one of the most outstanding researchers into mechanisms of activation of oncogenes and their function in the transformation process into malignant cells (Figure 2).

Pellicer was born in Tarragona, but exerted his talents investigating the molecular mechanisms of cancer in the Department of Pathology in the School of Medicine at the University of New York from 1977. In 1976 he obtained a PhD in Biochemistry from the University of Madrid, and the same year he did a residency in internal medicine at the Central Army Hospital. His doctoral thesis, on "The poly A polymerases of normal and transformed cells" was proposed and directed by Marisa Salas, and was in line with Salas's achievements on the molecular machinery of intra-cellular transformations as a part of enzymology, and thus of biochemistry. He dedicated his first efforts to the experimental approach of immunology in oyster. He landed in New York as a Postdoctoral fellow at the Institute of Cancer Research, Columbia University, Residency, with Richard Axel (thanks to the efforts of Jesús Ávila an older graduate student from the Viñuela \& Salas group in Madrid). It was in fact while being there, that he changed his project from the study of chromatin structure to the technique for inserting foreign genes into mammalian cells. After joining Michael Wigler (a graduate student that had initiated the experiments three months before his arrival in the I.B. Weinstein's lab) he undertook the very logical and remarkable experiments carried out on this transfection protocol that revolutionized DNA research. So climbing to the summit of his profession as a participant in the big oncogenes races of the early 1980s.

As he was a master at tissue culture techniques, that he had learnt in Madrid, he was also active in one of the keys to those experiments, ie to gather large quantities of Herpes virus DNA, the source to be used as transfected viral DNA. The experiment successfully used for the transfections this viral source to focus on the detection of the gene for the enzyme thymidine kinase in the mouse L cells deficient in thymidine kinase. The purified viral thymidine kinase gene had provided a model system for gene transfer. On May 1977 he published this first initial study [23]. In addition to DNA viral contamination, the detection approach in which Pellicer was involved achieved the molecular demonstration of the presence of the Herpes sequences into the transfected cells [25]. At this point he embarked on an experiment to attempt the transfer of eukaryotic genes into the recipient cells using total cellular DNA as donor. This complex was to be taken up by the cells and the nucleic acid be released within the cytoplasm or the nucleus. By validating the pioneering work carried out by adenovirologists in the early
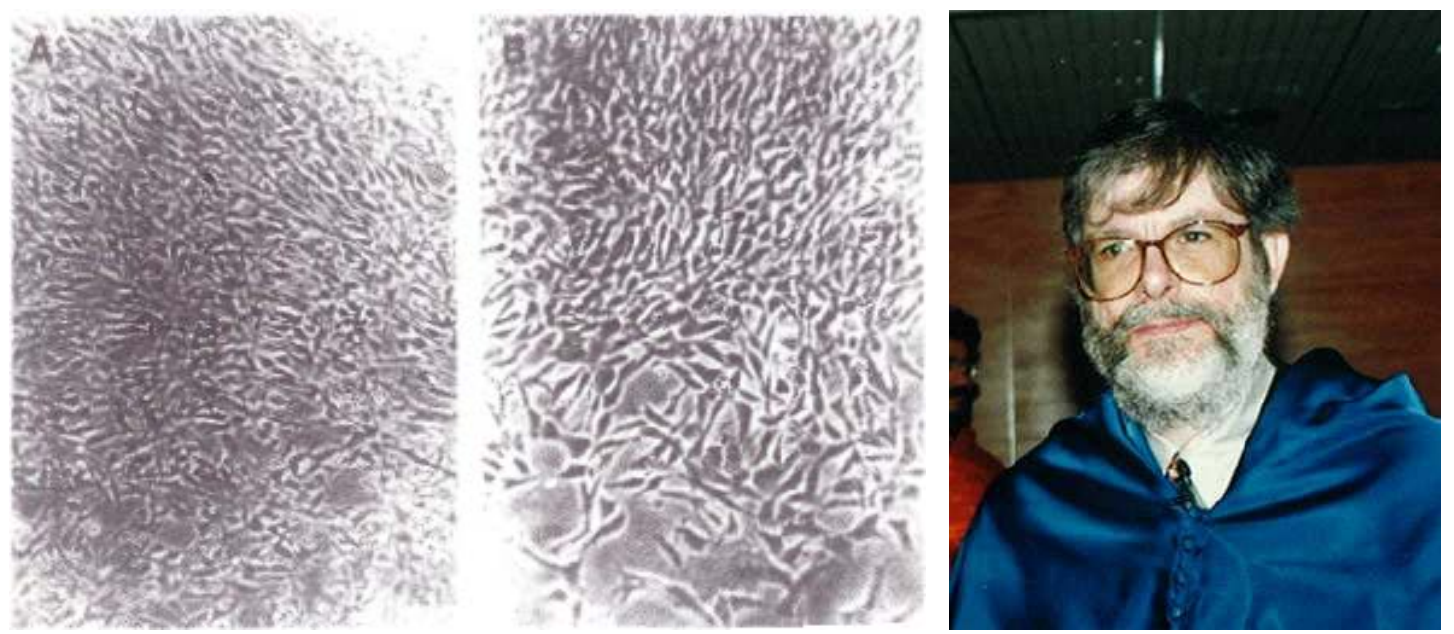

Figure 2. (Left) To produce a ras focus, Pellicer transfected the DNA from mice tumor cells induced by a dose of a chemical carcinogen and radiation into noncancerous NIH 3T3 cells. (Right) The Universitat Rovira i Virgili (Tarragona) conferred an honorary doctorate in sciences on him in 1997. 
1970s in The Netherlands, and despite a rather short efficiency in the precipitation of DNA as the carrier molecule (because the eukaryotic DNA is of much higher complexity). The difficulty was solved and after several attempts and subsequent modifications of the conditions of precipitation (involving one hundred tissue culture plates to maximize the chances of success) Pellicer simplified by using just ten plates and like the virologists he used DNA from a cell previously transfected with purified Herpes DNA and which he had proved before that contained a single copy of viral DNA.

To address the complex issue of the biological nature of transformation, defined as a change in genotype of a cell mediated by the introduction of DNA, he first reasoned that should total genomic DNA be used as donor, single-copy genes could be transferred. It was in fact then that was performed the transfection of an animal gene into an animal cell using total cellular DNA as donor, described in the influential "Biochemical transfer of single-copy eucaryotic genes using total cellular DNA as donor", published in 1978 [26]. Then that it was proved that single-copy genes can be transferred when total genomic DNA is used as donor. The impressive experiment had succeeded in the biochemical transformation of mutant mouse cells deficient in their function to produce the rodent enzyme thymidine kinase by the transfer of single copy cellular genes from various species of mammals or birds. The resultant percolated murine cells regained their capacity to produce the enzyme, as well as their positive thymidine kinase phenotype.

At this point of the demonstration, the reason for this uptake mechanism remained obscure and that could have stopped the experiments. Yet, on the contrary, Pellicer continued with new manipulations, such as cotransformation, the maintenance of intact plasmid function through passage in animal cells, construction of libraries of independent recombinant phage, and stress inducibility. Indeed very quickly, within a year, a rapid succession of experiments successfully carried out involved the seminal discovery that it was possible to generate stable cell lines for many generations in culture, by establishing that cotransfection with other pieces of DNA was attainable when one of the DNAs had a selectable marker [16]. The feasibility of co-transforming cells with two physically unlinked genes, this landmark experimental protocol which was the inmediate predecessor of the PCR technology, laid the foundations for the development of genetic engineering. Subsequently, as an index of the widespread applicability of DNA transfection techniques successful introduction of genes into stem cells was achieved [27]. The result expanded considerably the area of molecular genetics as the tumors derived from these cell lines were researched for the purpose of creating in vivo markers appropriate for analyses of gene regulation during embryogenesis. In December 1980 for the first time was exposed the experimental design which should permit the isolation of any gene which can be stably introduced into a recipient cell; the impressed result was achieved following the transformation of animal cells with a DNA preparation in which each molecule was physically linked to a bacterial plasmid. The purification of the first mammalian gene by genetic means had been obtained [28]. A final first from the initial outcomes of the experiments by Pellicer was the demonstrations that inducible promoters can be used to drive transfected genes. This was done on the basis of having shown that expression of cloned copies of the hsp 70 gene introduced into the genome of mouse tissue culture cells can be controlled by heat shock, indicating a considerable conservation of the regulatory signals [29]. Thus the promoter, like the sequence of DNA that controls the gene's expression, was spelt out as the location of the switch of the gene. As genes under the control of a Drosophila heat-shock promoter were transcribed only after a heat-shock in mammalian cells; the heat shock promoter, identified by site-specific mutagenesis, was able to confer stress inducibility. Thus the promoter mutation theory created its own path with a threshold in this experimental approach. A key contribution resulting from the collaboration with another alumnus from Eladio Viñuela and Margarita Salas’s Department, Victor González Corcés [30].

These superbly designed and exceptionally well organized series of manipulations proved to be deeply inspiring for many scientists during the next 35 years. His work previous to the engagement in molecular oncology at NYU was readily understood, mostly because the Columbia working atmosphere he was working in, stimulated him to describe all the technical details of his experiments in order to allow others to repeat them. As a result Pellicer not only reported accurate observations and phenomena, but also introduced his strong and logical experimental organization in two other spanish scientists. In the summer of 1978, Manuel Perucho went to a Gordon Conference on animal viruses in New York Àngel Pellicer communicated him his transfection results. It was the why Perucho moved away from Berlin Max Planck Institut für Molekulare Genetik to US CSHL and later to Stony Brook. Also in 1979, Mariano Barbacid, from the Laboratory of RNA Tumor Viruses, NCI, Bethesda went to New York, where Àngel Pellicer communicated him his transfection results. The interaction of these spanish biochemists with molecular oncology, under the base of their skills in the study of eukaryotic transcription, 
come into work on a basis of organic solidarity in which one scientist performed services which the others could not easily carry out for themselves. So there, these three molecular oncology research leaders met with oncogene.

\section{Manuel Perucho-Experimenter and Theoretician}

From 1979 onwards, Perucho counted as another prominent member of the spanish biochemist community in the US. Manuel Perucho became a collaborator with the eminent biochemist Eladio Viñuela (soon after spring 1971) in the Biological Research Center (CIB) of Madrid. There he continued to work fruitfully on the viral oncogene hypothesis inside the intellectual coherent set of key ideas of José and María L. Salas on DNA binding proteins from hamster fibroblasts, normal or transformed by oncogenic retroviruses. One of these proteins (P8), synthesized in these cultured mammalian cells, proved to be identical to an enzyme, the glyceraldehyde-3phosphate dehydrogenase. The research showed an uncontrolled synthesis of this enzyme that could be related to the altered glycolysis of the transformed cells (and glycolysis inhibition is a possible anticancer treatment). The speed with which Perucho had obtained P8 identity threw him into the race of working with RNA. As he was very eager to speculate and propose theories, such as for example that histone mRNA maturation might be mediated by RNA (an attractive explanation, because histone mRNA synthesis in typical eukaryotic cells is coupled tightly to DNA synthesis). And he moved to the Max-Planck-Institut für Genetik, Berlin (Germany). Where the importance of his theoretical contribution and essential observations inside the spanish phage group was promptly recognised [31]. But in Germany, where José-Antonio Campos-Ortega (a Valencia-born neurobiologist) had moved in 1965 [32], the biochemist Adolfo Ruiz-Carrillo inspired ideas behind the chromatin structure of the promoter region guided his steps to the Àngel Pellicer's lab in the NYU.

His change to the field of transfections was suggested to him by the Catalonian pathologist Pellicer; following his travel from Berlin to attend the 1978 Gordon conference on animal viruses. And in spite of the fact that mammalian cell transfection takes a month or two (when it works), within some months of his first arrival, Manuel Perucho was coming to work in the Cold Spring Harbor Laboratory in February 1979. Then, in May 1980, he convincingly showed in his first contribution to genetic transformations, without no more previous knowledge on a codified protein than its enzymatic activity, that the thymidine kinase (tk) gene could be cloned. Indeed the chicken TK gene (that is very small and so easy to be rescued from cell genome after EcoRI digestion) was the first superior eukaryote to be isolated by purely genetic procedures. Indeed, he reported, through an elegant protocol, that for TK genes classical methods of molecular cloning dependent on messenger RNA (mRNA) enrichment were exceedingly difficult [33]. Contrary to the approach of Pellicer, his scheme relied on the maintenance of intact plasmid function through passage in animal cells. The experiment showed beyond any doubt that Perucho beautifully mastered the experimental methodology, both regarding his speed at the bench, and with respect to the development of a genuine experimental semantic to describe the approach and results. This latter issue was of paramount importance, not only to properly communicate, but also to reinforce epistemological convergence between Pellicer and Perucho.

Soon after he became aware of the new laboratory methods in enzymology, incorporating transfection cells and learnt from Pellicer, J.D. Watson decided (in March 1980) to communicate their results to the National Academy of Science. The cells Siminovitch handed them were chinese hamster ovary (CHO) cells that had been made resistant to methotrexate (Mtx). They isolated the DNA from the hamster, applied it to NIH 3T3 cells, and incubated these mouse cells for two weeks. As a result, they showed that the introduced gene was amplified in the new cellular environment, if the initial transformant was doused with increased levels of this drug. Here again, the experimental strategy was properly thought over as the restriction profiles of these two species were sufficiently different to permit them to detect the hamster gene in the presence of an endogenous mouse gene [34]. And the protocol was even used by them in order to more research DNA mediated gene transfer and later with transforming genes, also known as oncogenes. Subsequently, this procedure and strategy led to the description of the physical linkage and recombination of all these exogenous sequences of DNA inside the genome of the transformed cell; once they were ligated together into a new genetic unit which may sometimes attain a size equivalent to $1 \%$ of the cell genome. The transformed cells carried several copies of transferred DNA which must, therefore, be replicated. An important practical result because genes isolation was facilitated by using antibodies or by other criteria not involving metabolic pathway or morphological change [35].

While transfection work shed light on how animal cells may be transferred from cell to cell and expressed with ease. To provide a mechanism which explains how and why the progression of a cell lineage from nor- 
malcy to malignancy may involve the mutation or activation of one or more genes. Started from the 1980s, new avenues of research opened for the etiopathogenetic study of cancer with the discovery that foci derived from three different human tumor cell lines (from lung and colon carcinoma) contained a defined genetic element that was responsible for the transformation of NIH-3T3 cells [17]. An eloquent example of the validity of the pioneering work carried out with tumour viruses during the 1960s and 1970s, considering the special role in the generation of some of the key experiments by members of a research school established around Ochoa.

The new model of oncogenesis (the genomes of retroviruses contain candidates for such "oncogenes") made that a short-range migration between adjacent groups happened to work into the same new specialty. Thus for a period of time there were three groups within a small elite. Pellicer, Barbacid and Perucho demonstrated in a number of ways the evolution of a new and powerful technique for the study of human neoplasia. Perucho was a prominent contributor to this important movement. He observed that DNA of high molecular weight from various tumor cell lines and from other primary tumors had the capacity to "transform" NIH3T3 cells when supplied as a calcium phosphate coprecipitate. The transforming activity is manifested by a low efficiency of focus induction, that is to say clonal growth of morphologically altered cells and with a higher growth potential than in not transformed NIH/3T3, that have their growth inhibited by contact. The transformation of the NIH3T3 receptor cells derive from the incorporation of donor DNA that, in a dominant form, gives rise to an altered growth and morphological changes. For the interest that focused on the molecular clonage of DNA sequences with "transforming" potential the oncogene was discussed, it being thought that these genes were probably responsible for the neoplasic phenotypes in the tumoral cells from which they come. The origin of these primary transformants was unclear. Although Pellicer identified these oncogenes in animal models with tumors chemically induced [36].

For Perucho, the cause of cancer would be DNA mutations; his hypothesis will become that "cancer is a mutator phenotype", its explanation will complement and expand the mutational theory of cancer through the existence of a remote mutator mutation. This important theoretical work on the fundamentals of cancer cause and its explanation at the subcellular and cellular levels of biological organization, have been the result of his observation and description of the first three mammalian ras genes. By 1981, using gene transfer assays, he had established the dominant existence of oncogenes in humans, and he cloned and sequenced in at least two mammalian species the genetic units included in the ras family then comprising three genes that encode highly homologous protein isoforms: $\mathrm{H}-, \mathrm{N}-$, and K-Ras. In April 1982 was published the clonage and sequencing the human c-H-ras [18], in January 1983 the transforming oncogene (N-ras) of a human neuroblastome cell line (which he also identified for the first time) [37], and in January 1984 the transforming sequences (c-K-ras) of two lung carcinomas [38] (Figure 3). This small gene family that established the molecular basis of neoplasia took its name from the words rat sarcoma because they were first identified as the transforming principle of the Harvey and Kirsten strains of rat sarcoma viruses.

Perucho's grand intellectual framework comprised the proof of existence of a transforming gene in human tumors by the molecular cloning of a human transforming gene from the T-24 urinary bladder carcinoma cell lines (Barbacid would proof that this cellular sequence could be activated by subtle genetic alterations). And received once more time the support and encouragement of J. D. Watson [18]. But included a large component of
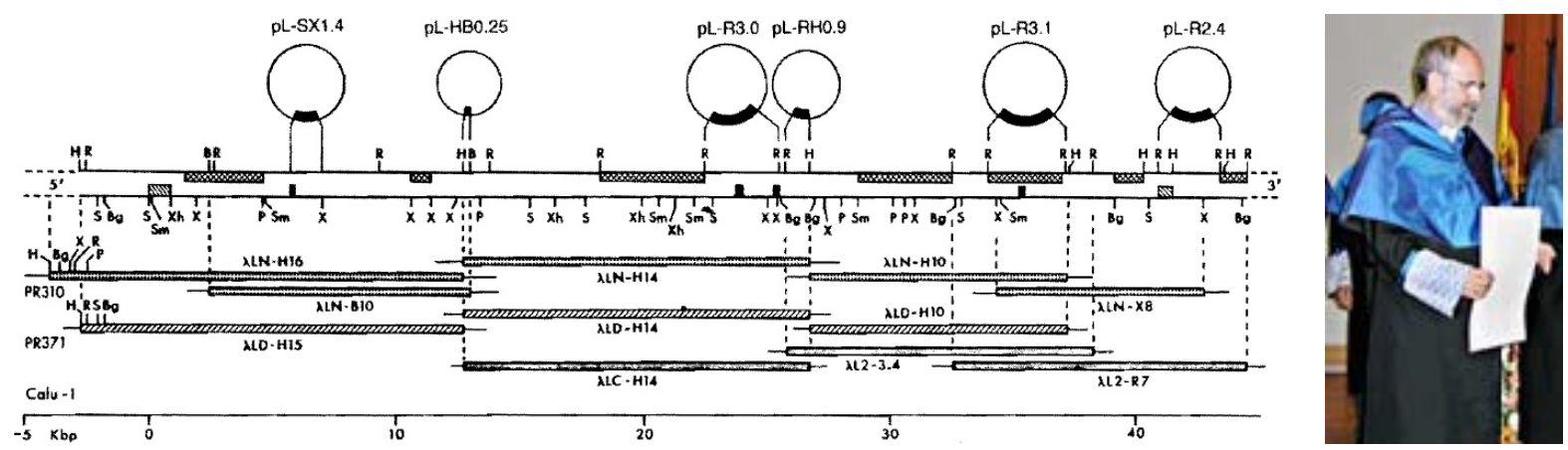

Figure 3. (Left) Structure of the c-K-ras human oncogene from lung carcinomas [38]. (Right) Professor Manuel Perucho was granted the Doctor honoris causa degree by the Universidad Pablo Olavide (Seville) in May 2005. He who first cloned a human oncogene, in 1982, from the T24 bladder tumor cells (it had the same transforming properties as the oncogenes from retroviruses), contributed to the foundation of the Andalusian developmental biology center (CABD). 
technique. Severo Ochoa with the aim of communicating his synthesis to the National Academy of Science, made available a procedure of examination of a large set of tumours that provided an accurate measure of the transforming potential of the altered ras genes. The demand for more rapid techniques for the detection of mutant ras genes led to profit from the advances in the molecular techniques especially the polymerase chain reaction (PCR). And latter the characterisation of the hot-spots of the mutations, made it possible to examine directly the tumor DNA for mutations in specific sites of the ras genes. The presence of mutations in ras genes as well as their nature and position was determined by RNase A mismatch cleavage [39]. This assay for the diagnostic detection was allowing an estimation of both normal and mutant ras alleles in the same tumor cells. For a period of time, as the argument concerned the oncogenic transformation of DNA diagnostic, the procedure took a vigorous part in many of the discussions on cancer screening.

\section{Mariano Barbacid}

Mariano Barbacid (1949-) was the most prominent spanish biochemist in US, during this period (Figure 4). Born in Madrid, the scientist had leave his country for professional reasons in 1974, acquired US residence for 24 years, and ended up in Madrid by 1998, where he soon became extremely influential in state science affairs, as well as in university politics. In 1970, he eventually joined David Vázquez (prokaryotic translational control) in the Biological research center (CIB), and became doctor in 1974, after the old CIB had been transformed in the Institute of cellular biology inside the Higher council for scientific research (CSIC). With a doctoral dissertation which was on antibiotics interactions with eukaryotic ribosomes at the acceptor site of the peptidyltransferase centre, he helped to popularize all the sesquioterpene antibiotics which are very active inhibitors in the peptide bond formation step. In the brief time (3 years) Dr. Barbacid walked upon this centre, together with Àngel Pellicer, Manuel Perucho and Jesús Ávila, he was trained in scientific rigour and in having fun with the experiments and the acquisition of knowledge.

The point of departure for Barbacid in the US was the study of leukemia viruses at Stuart Aaronson lab in the National Cancer Institute (NCI), Bethesda, Maryland. Two viruses play prominent roles: the Friend virus, named after its discoverer Charlotte Friend, and the MCF (mink cell focus-inducing) virus, an abbreviation for minkcell-focus-forming virus. From this laboratory of RNA Pathogenic strains of Friend murine erythroleukemia virus have the capacity to induce rapid proliferation of erythroid precursor cells within days after innoculation into adult mice of susceptible strains. The Friend murine leukemia virus was isolated in 1957 by passage of cell-free extracts of Erlich ascites carcinoma cells in newborn Swiss mice. The virus consists of at least two components: one component is called the spleen focus-forming virus (SFFV) because of its ability to induce discrete foci of transformed cells in the spleens of infected mice, and another component has also been identified. Using cell

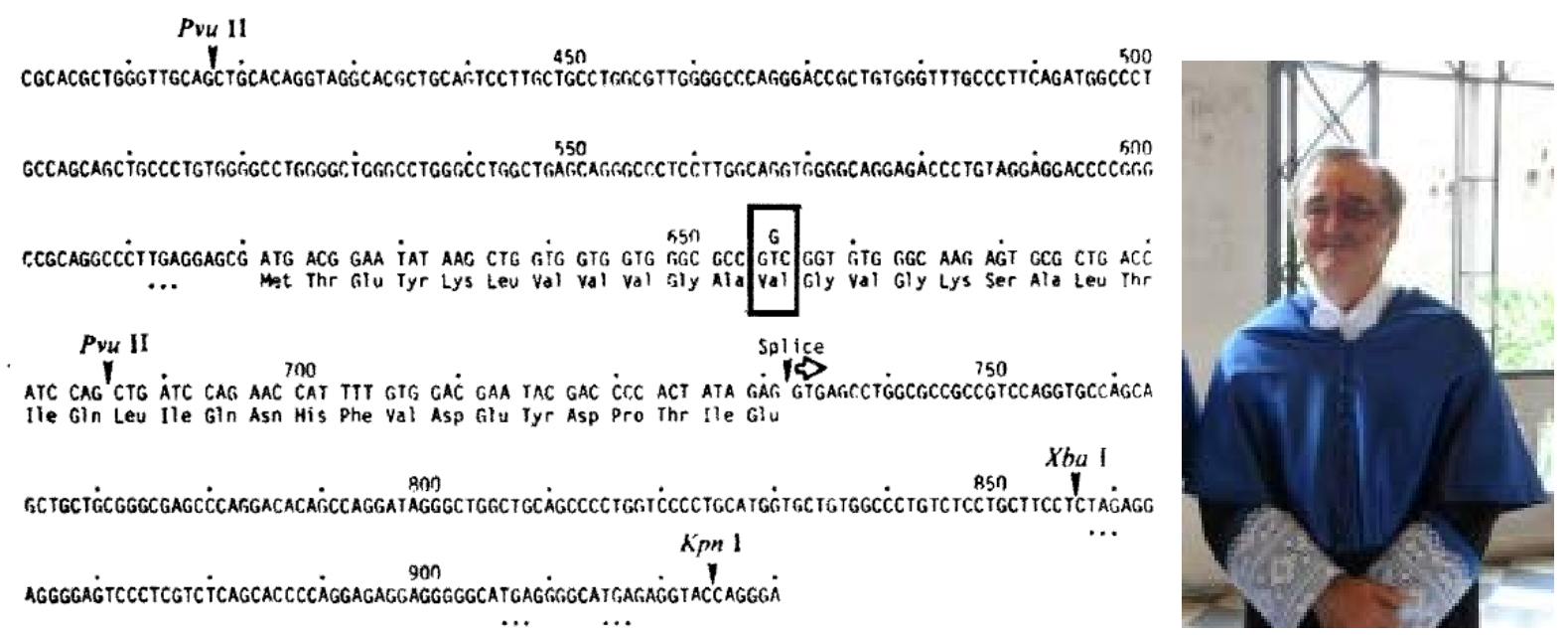

Figure 4. (Left) Barbacid found in 1982 the first mutation associated with the development of human cancer. That the ras gene mutated at twelfth codon, resulting in the incorporation of glycine, instead of valine, was the only responsible for the human bladder cancer. (Right) Dr. Barbacid has been honoured with "Doctor Honoris Causa” Degree from three Spanish universities (Universidad Internacional Menéndez y Pelayo (1995), University of Cantabria (2011) and University of Barcelona (2014)). 
lines and radioimmunoassay techniques for detecting viral antigens, Barbacid reported that the Friend virus encodes a protein that is structurally and immunologically indistinguishable from the $\mathrm{p} 15$ polypeptide encoded by the Friend murine leukemia virus (F-MuLV) [40]. The cell surface localization of this translational product has been studied, and a relation was found with the glycoproteins of the viral envelope. However genetic experiments revealed that expression of this protein is not required for malignant transformation [41].

On several occasions Emilio Muñoz (from the Cellular Biology Institute (Madrid) where Barbacid did his doctoral work) outlined the special difficulties of the relationship concerning membrane technology and glycoproteins. For example, in 1975, he opened an important paper with such a discussion and suggested a topological distribution of glycoproteins in membranes [42]. Following his instructions regarding this technology (that makes peptide maps show that F-SFFV glycoproteins share peptides with those of both murine leukemia viruses (MuLVs) and MCF-MuLVs), Barbacid turned to the relationship between the viral envelope and the murine leukemia virus related gene products. And once he started, in 1978, his own group to work on the molecular biology of human tumors he became aware that these viruses had been shown to be highly oncogenic, causing lymphomas in susceptible hosts [43]. It is clear that he valued the concept of a common gene progenitor in the evolution of oncoviruses (on the base of immunologic and biochemical relatedness of gag gene translational products), when he decided to investigate the induction of tumors in mouse models. Here again, the experimental strategy was returning to the question of the genome structure of Friend virus which could bear on its leukemogenic properties, and the recombinant nature of SFFV. As it had not been indicated whether the wild mouse viruses were genetically transmitted, and the activation of a cell line for production of a transmissible virus-induced lymphocytic leukemia has became important. When Àngel Pellicer introduced him to the transfection technology, in 1979, his first effort was directed to attempt the definition of the regions of sarcoma viruses involved in neoplasia.

Indeed he had properly thought over how to recognize type-specific antigenic determinants that readily distinguished sarcoma virus isolates. But the transfection techniques as an experimental strategy for cloning genes encoding DNA-binding proteins, made it possible to attempt the definition of the regions of the Feline sarcoma virus (ST-FeSV) genome involved in neoplasia. From the initial suspiction that it was possible to tell from the translational product ST P85 [44] of the ST-FeSV which were the proviral sequences involved in malignant transformation. Barbacid went on seeking the connection between tumor proteins and the ST-P85-associated protein kinase activity. Because gene products exhibiting an associated tyrosine-specific protein kinase activity were in those days one of the scarce proofs scientists had into the biochemistry of cancer. He supposed that precisely the proviral sequences necessary for ST P85 expression were involved in malignant transformation. And found that the cat cellular genome possessed at least two subsets of transducible genetic information with different oncogenic properties. The expression of P85 appeared to be necessary, but not sufficient, for the establishment and maintenance of the transformed phenotype. And as the mink cell focus-inducing (MCF) virus may also play a causal role in cancer, clones of these cells containing mutants of ST-FeSV were relevant because of their dephosphorylated activity. This suggested that a member of the viral tyrosine kinase family, isolated from mammalian cells infected with feline sarcoma virus, P85 could induce cellular transformation by modulating the control of cell growth.

In the presence of this persuasive evidence, Barbacid turned to the problem on the malignant transformation of eukaryotic cells. The oncogens of normal and tumor cells differ from viral oncogenes in their more complicated structure. And the emerging field, that also used transfection, was called oncogenetics. Following Pellicer, to understand genetic predisposition to cancers Barbacid, unlike most researchers in the field, who chosed human tumors, opted for the use of animal model systems of tumorigenesis to analyze the role of these malignant genes in tumor evelopment. The conceptual analysis of ras mutations was to be studied by activating DNA from a variety of solid human tumors as well as from established human tumor cell lines once it was introduced in murine NIH 3T3. cells. On the path of Àngel Pellicer recombinant DNA technique had been achieved and together with Mariano Barbacid widely applied for studying oncogene structure and function.

Barbacid had discovered that phosphorylation of tyrosine residues was associated with cellular transformation, thus announcing common pathways in exerting oncogenic potential [44]. To chart these signalling pathways the ancient evolutionary origin of the genes suggested that tyrosine phosphorylation could play an important role in eukaryotic cellular physiology. So potentially oncogenic sequences have been conserved during the evolution of animal genomes, and have been acquired by sarcoma viruses. After having shown that cells transformed by sarcoma viruses whose transforming gene products exhibit an associated tyrosine-specific protein kinase, contain 
higher overall levels of phosphotyrosine residues than uninfected cells. And once he proposed some minor modifications [45] to the protocol of Pellicer, Barbacid, a leading translational researcher who never worked on transfection himself, did run his laboratory into the 1982 and 1983 races concerning isolation, identification, cellular localization, deciphering of primary structure, and properties of the proteins coded by the retroviral oncogenes. Basically, in demostrating the existence of transforming genes inside all human cells than can mutate or get "turned on" and become tumor cells, and that viruses could actually carry in these "oncogenes". A neverbefore-told story, where as it goes, for the first time it was demonstrated that human tumors contained activated oncogenes, related to those picked up by retroviruses from their host genomes. In the words of Ochoa, Barbacid purified the oncogenic protein, practically to homogeneity, and through his interesting studies he found that the effect of injecting this protein in sensitive cells lead to a transformation. Nevertheless the protein was finally degraded, the transforming state was reverted, and once more the normal phenotype reappeared.

Reflecting on his accomplishments, Barbacid recognized three best results. It was a big jump the identification of transforming genes in human tumors, because he had sixty tumor cell lines, eight showed transforming activity, whilst seven of the forty-four solid tumors, in all organs, were positive in the transcription assay into NIH 3 T3 cells. In addition, a really interesting biological result in this assay was that all the transforming genes identified were members of the ras genetic family (with two exceptions) [46]. But he was pretty succesful when he came to apply the large body of knowledge concerning retrovirus to the malignant activation of ras oncogenes in human tumors through repeated somatic mutations. Barbacid had discovered that the transforming properties associated with the T-24 hepatic carcinoma H-ras locus were conferred by a single point mutation [47]. As thrilling as these experiments was to provide the evidence that transformant genes were present in animal tumors experimentally induced [48].

\section{The Oncogenetics Goes on}

Without discussing too much the situation in the early chronicle of ras research (that can be traced back to 1964), we will like to complement this exploration of the spanish work in the onset of oncogenetics, as the science of oncogenes, by adding a few words to see how this new specialty in molecular biology was generated. Shortly after its inception back in 1971, recombinant DNA technology saw a first spanish presence when José Salas, from the community of scientists formed around Ochoa, began using the human cell line established by Szybalski, that could transfer an enzymatic capacity to mutant cells having lost it [49]. Salas achieved a shearing experiment, the hybrid clones produced could accommodate receptors and other gene products derived from both species of polio and polyoma viruses. The tool was available and the idea was to use it for polio sensitivity experiments with human-mouse hybrid cell lines [50]. Manuel Perucho responded in 1977, when the methods of gene transfer were fully successful, fashioning the result to discover the protein-P8 identity [51]. Until this date, methodological efforts of gene transfer suffered much from the use of low complexity DNA. What made Àngel Pellicer to conclude that only subsequent improvements made the transfer feasible using total vertebrate and mammalian DNA. This early intervention of spanish biochemists into the development of the transformation techniques (the route to recombinant-DNA through DNA-mediated gene transference) is associated also to Mariano Barbacid, at the time in the US with Aaronson, who in the last sixties had focused on normal embryonic fibroblasts as strains transfected in NIH 3T3 cells to detect transforming activity.

The protocol for these studies involved transfer of total cellular DNA and was at the base for a simple screening procedure that can distinguish the normal gene from the oncogene. If they created a recombinant of the viral genes present in bladder oncogene and the cellular genes in its normal cellular counterparts, and they assayed them for their ability to transform cells. When with restriction enzymes they mapped the clone with the transforming phenotype, they observed that the single distinction between the normal gene and the oncogene was a sole mutagenized change. The move in the original ras for the clone with the point mutation meant that, a transversion from thymine to guanine would lead to the substitution of valine for glycine in the oncogene. A single mutation point in the ras gene invited to resist facing restriction enzyme cleavage. And as mutated ras is found in approximately $30 \%$ of all human cancers, such protein constructs became a possibility to induce through drugs apoptosis in differentially sensitized tumoral cells. In the emergence of oncogenetics from the identification work of the first human oncogene, the first axe that unified the direction of research was simple. As Ochoa put it, glycine could be changed into another aminoacid just with a single mutation, an extremely simple change, the result of which was that: a gene which did not spread out in oncogenic products was transformed into one 
that did it. In the conditions under which the complexity of nature gets made simpler, found the new specialty a relatively high degree of consensus. One that made these pioneer scientists think about multistep carcinogenesis (Table 1), and establish subspecialties within the oncogenetic specialty.

The fact that in every cell and moment single mutations could occur, formed the point of nucleation for what was developing into a new discipline. The idea integrated into a rodent model, made Pellicer design the induction for the clone with the point mutation in diverse animal systems. This was a major step in the chronicle of ras discovery that led to much research. Ras was found to be activated by mitogenic factors [52]. He could add to his list of accomplishments that among these tumors systems the question was raised of whether the mutations were necessary for tumorigenesis. The elegant techniques designed by him on the human ras family validated his work with oncogenes, as the one who first isolated genes identified as important genetic components of viruses which could directly be activated and induce tumours in experimental animals. He provided evidence that the only activated mechanisms for ras genes leading to tumorigenesis were point mutations in some crucial codons. In this way it was worth to say that dominant ras mutations could be oncogenic. And that as a response to the experimental loss of the normal allele, he observed that ras mutations were an early event during tumor development. So Pellicer revealed the most dramatic links between murine models and carcinogenic agents through its characterization in transgenic and gene-targeted mouse models.

With the objective in mind to see a diagnostic procedure Ochoa soft-spoken manner had witnessed his most perfect method to detect point mutations ever in a novel experimental approach that he presented to the National Academy of Sciences. In a bright and pioneering but short paper in 1985, Perucho made it possible to examine directly the tumour DNA for mutations in specific sites of the ras genes [41]. Ochoa might appreciate this sweet triumph where the diagnoses were not known front of, meaning the researchers had established a precursor in this topical field. Indeed, the method was fast and was likely to be used for large screening, although subsequent developments of PCR based assays (by the same group) led to even more rapid techniques for the detection of mutant ras genes. The analysis of c-K-ras mutations in pancreatic cancer continued the study of the molecular genetics of pancreatic carcinoma in which Perucho was involved at Stony Brook from 1983. Inside almost all cells of the pancreas that can mutate or get turned on and become tumor cells there are c-k-ras genes. The method probed that the hybridization solution of genomic DNA which links the tumour probes to the RNA was changed by addition of pancreatic ribonuclease (RNase A). He measured the hybrid molecules mutational level by running the DNA mismatched in a polyacrylamid gel. And the differential hybridization with restriction site length polymorphisms were very specific for a single mutation. As it turns out this RNase A mismatch cleavage method was a bit of a jump, it anticipated the impressive methodology later on developed to perform molecular karyotypes by using DNA fingerprinting, and deserved credit again from Ochoa.

Ochoa had also acknowledged the biochemical assay for making the distinction between normal and transforming $\mathrm{H}$-ras genes. But the teachings of Barbacid with the mutated K-ras gene in lung tumors, were happier still when he found this oncogene in a biopsy from a 66-year-old cancer patient. He also examined normal tissue in his parenchyma and white blood cells, but they didn't show the activating mutation detected in tumor tissue. To get the answer sure, DNA was isolated from the man's normal tissues, and snapped into nonmetastatic 3T3 cells. The result was no effect. So the concept was established, oncogene presence was specifically triggering the development of human cancer [53]. The oncogene was not a "laboratory artifact", yet a key decoder of the identity of cancer. Phalanxes of scientists have converged on a fierce pursuit of ras mutations in human cancers subsequently, in light of this success. To understand oncogenes in precise detail, it was argued whether they were underlying the initiation in human tumors or their importance was blown by being merely activated as a consequence of the genetic instability of malignant cells. The diagnostic of nitroso-methylurea (NMU) induced mutagenesis in four tumorigenic guinea pig cell lines, tooled mutated ras oncogenes hidden inside them. Indeed,

\begin{tabular}{l} 
Table 1. Subjects within oncogenetics by 1986. \\
\hline Mechanisms of oncogenesis \\
Location of oncogenes \\
Anti-oncogenes \\
Amplification of cellular oncogenes \\
Growth factors and oncogenes \\
Evolution of tumors and the impact on molecular roots of cancer
\end{tabular}


in 1985, evidence was offered by Barbacid for the initial event in the neoplastic change, by activating H-ras oncogenes. The first identification of an oncogene as a target for a chemical carcinogen. Its activating lesion was mutation-specific (by using a frequent substitution during tumor development), with all the concomitant projecting charisma of the initiation event into a cancer.

The described experimental protocols provided by Pellicer and Barbacid were the essential contribution to what is considered by some as the birth of oncogenetics. While Pellicer results looked assured, for in experimental animals, ras activation was associated with tumoral induction. The knowledge generated by Barbacid studies determined hopes to device clinical interventions of cancer. In fact, subsequent experiments by Perucho constituted an essential step on the way to the elaboration of a general diagnostic methodology, which finally acquired its status with the PCR test. The tradition of Ochoa, with his gifted spanish contacts in the US, the fact that he was behind the scenes in order to clarify the basic rights on the most abundant exemples of priority. Can be considered to follow the major conceptual and pragmatic rules of scientific schools. First, they explictly viewed their prominent hypothesis presented to the National Academy of Sciences. Secondly, and as a consequence, their subsequent research used this new perception and activated the potentialities inside the ideal of what the true scientist should be credited by the leading biochemists. Much attention must point to these interesting problems for further research, which may eventually enable to establish the different roles of Ochoa's school in the origins of oncogenetics.

\section{Conclusions}

A three decade-long tradition has established the role of ras genes in neoplasia. Consolidation of oncogenetics, as the science of ras genes, ras oncogenes and cancer, has brought about the spanish oncologists followers of Ochoa perspective that validate the pioneering work carried out with tumour viruses during the 1960s and 1970s. In a few febrile years, during the early eighties, these researchers revealed that the common characteristic shared by these genes, their vulnerability to mutation, played a crucial role in the primary events that triggered the cancer. These outstanding result in ras research shows the way not only to solve the challenging views behind ras biology, but their models of success are also larger as they face the development of efficacious drugs that could have a significant impact on cancer treatment.

It is fair to say that, if not a school, a solid tradition in biochemistry was built up by many scientists from Spain in the US, which contributed to the long-standing reputation of Ochoa in this discipline. Àngel Pellicer, a very gifted experimenter at Columbia University followed Graham-van der Eb calcium-phosphate DNA-precipitation technique to successfully transfer a chicken gene for the enzyme thymidine kinase into mouse cells that lacked the ability to produce the enzyme. This method and others developed by him between 1977 and 1980 marked a real breakthrough in the field of transfection, because they permitted the stable introduction, inside cultured mammary cells, of any cloned gene, or of a non-clone gene if it is isolated via transfection. Pellicer passed on his transfection expertise to somebody else. The honor fell to Manuel Perucho and Mariano Barbacid. Manuel Perucho was the first scientist to clone a human oncogene; by 1981, using gene transfer assays, he established the dominant existence of oncogenes in humans. He subsequently cloned and sequenced the three genes then included in the ras family: $\mathrm{H}-, \mathrm{N}$-, and $\mathrm{K}$-Ras. His hypothesis will become that cancer is a mutator phenotype, and it directly concerned molecular techniques like polymerase chain reaction (PCR), associated to the diagnostic detection of the altered ras genes. The discovery of the point mutation in racing at the forefront of oncogene research marked Barbacid's work as one of the milestones in cancer research. If Pellicer's transfection assays permitted to detect mutant genes in tumor cells, and Perucho, through cloning the gene, was able to define in detail which was the genetic element responsible for the malignant transformation of cancerous cells, the mechanism of activation caused by a modest point mutation found by Mariano Barbacid and published in late 1982 was a turning point. By that time, the first human ras oncogene had been cloned one year earlier, and according to the Barbacid's schema the human proof of the moment of succumbing to the transition from glycine to valine in human cancer had been provided. Thus facilitating the point in cancer treatment doctors could rooting out the problem at source.

In the search for effective cancer therapies the molecular detail about how the ras proteins function is very valuable, as they possess the ability to regulate cell growth and malignant transformation. Therapies that target the ras proteins are showing promise in the clinic and many more are being developed. They were discovered as retroviral oncogenes carried by rat genome. But human DNA sequence homologous to these transforming genes 
of rat sarcoma virus posed the question that if those oncogenes transduced by retroviruses could be mutated in human cancer. Searches for transfectable oncogenes in the genome of human tumours rediscovered the ras genes. So through the association of human cancer with virus-induced tumors of rodents were isolated the human oncogenes. But the contribution of Ochoa's school soon made clear that these tumour- or retrovirus-derived forms of the ras genes encoded within their coding sequences proteins that acquired constitutive activity because of point mutations. This knowledge is now being used to design rational therapies that target the ras pathways.

\section{Acknowledgements}

This is a revised version of a paper originally presented at the 6th International Conference of the European Society for the History of Science, University of Lisbon, Lisbon, 4-6 September 2014.

\section{References}

[1] Cantor, D. (2012) Between Prevention and Therapy: Gio Batta Gori and the National Cancer Institute’s Diet, Nutrition and Cancer Programme, 1974-1978. Medical History, 56, 531-561. http://dx.doi.org/10.1017/mdh.2012.73

[2] Pickstone, J.V. (2007) Contested Cumulations: Configurations of Cancer Treatments through the Twentieth Century. Bulletin of the History of Medicine, 81, 164-196. http://dx.doi.org/10.1353/bhm.2007.0011

[3] Moscucci, O. (2005) Gender and Cancer in Britain, 1860-1910: The Emergence of Cancer as a Public Health Concern. American Journal of Public Health, 95, 1312-1321. http://dx.doi.org/10.2105/AJPH.2004.046458

[4] Vineis, P., Schatzkin, A. and Potter, J.D. (2010) Models of Carcinogenesis: An Overview. Carcinogenesis, 31, 17031709. http://dx.doi.org/10.1093/carcin/bgq087

[5] Coste, J. and Lepiège, A. (2009) Toward Epistemiology and History of Epidemiology. Revue d'Épidémiologie et de Santé Publique, 57, 317-318. http://dx.doi.org/10.1016/j.respe.2009.06.007

[6] Fantini, B. (2006) Of Arrows and Flows, Causality, Determination, and Specificity in the Central Dogma of Molecular Biology. History and Philosophy of the Life Sciences, 28, 567-593.

[7] Keating, P. and Cambrosio A. (2007) Cancer Clinical Trials: The Emergence and Development of a New Style of Practice. Bulletin of the History of Medicine, 81, 197-223. http://dx.doi.org/10.1353/bhm.2007.0003

[8] Beatson International Cancer Conference (2006) 24 Years : Ras and Human Cancer. 18-21 June 2006, Glasgow.

[9] Angier, N. (2014) Natural Obsessions: Striving to Unlock the Deepest Secrets of the Cancer Cell. Houghton Mifflin Company, Boston.

[10] Barbacid, M. (2003) Eladio Viñuela : Pionero de la biología molecular en España. In: Ávila, J., Perucho, M. and LópezOtín, C., Eds., El fago phi29 y los orígenes de la biología molecular en España, CSIC, Madrid.

[11] Barona Vilar, J.L. (2010) El exilio científico republicano. PUV, València.

[12] Giral, F. (1994) Ciencia española en el exilio (1939-1989): El exilio de los científicos españoles. Centro de Investigación y Estudios Republicanos (CIERE), Madrid.

[13] Ochoa, S. (1960) Síntesis enzimática del ácido ribonucleico. Ciencia, 20, 1-14. http://cedros.residencia.csic.es/imagenes/Portal/ciencia/1960_20_01-02-z2.pdf

[14] Ochoa, S. (1980) A Pursuit of a Hobby. Annual Review of Biochemistry, 49, 1-31. http://dx.doi.org/10.1146/annurev.bi.49.070180.000245

[15] (2004) Folkman, Hunter, Massague, Vogelstein and Weinberg Win 2004 Prince of Asturias Awards. Cancer Biology \& Therapy, 3, 585-592. http://dx.doi.org/10.4161/cbt.3.7.1050

[16] Wigler, M., Sweet, R., Sim, G.K., Wold, B., Pellicer, A., Lacy, E., Maniatis, T., Silverstein, S. and Axel, R. (1979) Transformation of Mammalian Cells with Genes from Procaryotes and Eucaryotes. Cell, 16, 777-785. http://dx.doi.org/10.1016/0092-8674(79)90093-X

[17] Perucho, M., Goldfarb, M., Shimizu, K., Lama, C., Fogh, J. and Wigler, M. (1981) Human-Tumor-Derived Cell Lines Contain Common and Different Transforming Genes. Cell, 27, 467-476. http://dx.doi.org/10.1016/0092-8674(81)90388-3

[18] Goldfarb, M., Shimizu, K., Perucho, M. and Wigler, M. (1982) Isolation and Preliminary Characterization of a Human Transforming Gene from T24 Bladder Carcinoma Cells. Nature, 296, 404-409. http://dx.doi.org/10.1038/296404a0

[19] Pulciani, S., Santos, E., Lauver, A.V., Long, L.K., Robbins, K.C. and Barbacid, M. (1982) Oncogenes in Human Tumor Cell Lines: Molecular Cloning of a Transforming Gene from Human Bladder Carcinoma Cells. Proceedings of the National Academy of Sciences of the United States of America, 79, 2845-2849.

http://dx.doi.org/10.1073/pnas.79.9.2845 
[20] Malumbres, M. and Barbacid, M. (2003) RAS Oncogenes: The First 30 Years. Nature Reviews Cancer, 3, $459-465$. http://dx.doi.org/10.1038/nrc1097

[21] Morange, M. (2007) The Field of Cancer Research: An Indicator of Present Transformations in Biology. Oncogene, 26, 7607-7610. http://dx.doi.org/10.1038/sj.onc.1210583

[22] Morange, M. (1997) From the Regulatory Vision of Cancer to the Oncogene Paradigm, 1975-1985. Journal of the History of Biology, 30, 1-29. http://dx.doi.org/10.1023/A:1004255309721

[23] Wigler, M., Silverstein, S., Lee, S.L., Pellicer, A., Cheng, Y.C. and Axel, R. (1977) Transfer of Purified Herpes Virus Thymidine Kinase Gene to Cultured Mouse Gene Cells. Cell, 11, 223-233. http://dx.doi.org/10.1016/0092-8674(77)90333-6

[24] Wigler, M., Pellicer, A., Silverstein, S., Axel, R., Urlaub, G. and Chasin, L. (1979) DNA-Mediated Transfer of the Adenine Phosphoribosyltransferase Locus into Mammalian Cells. Proceedings of the National Academy of Sciences of the United States of America, 76, 1373-1376. http://dx.doi.org/10.1073/pnas.76.3.1373

[25] Pellicer, A., Wigler, M., Axel, R. and Silverstein, S. (1978) The Transfer and Stable Integration of the HSV Thymidine Kinase Gene into Mouse Cells. Cell, 14, 133-141. http://dx.doi.org/10.1016/0092-8674(78)90308-2

[26] Wigler, M., Pellicer, A., Silverstein, S. and Axel, R. (1978) Biochemical Transfer of Single-Copy Eucaryotic Genes Using Total Cellular DNA as Donor. Cell, 14, 725-731. http://dx.doi.org/10.1016/0092-8674(78)90254-4

[27] Pellicer, A., Robins, D., Wold, B., Sweet, R., Jackson, J., Lowy, I., Roberts, J., Sim, G.K., Silverstein, S. and Axel, R. (1980) Altering Genotype and Phenotype by DNA-Mediated Gene Transfer. Science, 209, 1414-1422. http://dx.doi.org/10.1126/science.7414320

[28] Lowy, I., Pellicer, A., Jackson, J.F., Sim, G.K., Silverstein, S. and Axel, R. (1980) Isolation of Transforming DNA: Cloning the Hamster Aprt Gene. Cell, 22, 817-823. http://dx.doi.org/10.1016/0092-8674(80)90558-9

[29] Pelham, H.R.B. (1982) A Regulatory Upstream Promoter Element in the Drosophila Hsp 70 Heat-Shock Gene. Cell, 30, 517-528. http://dx.doi.org/10.1016/0092-8674(82)90249-5

[30] Corcés, V., Pellicer, A., Axel, R. and Meselson, M. (1981) Integration, Transcription, and Control of a Drosophila Heat Shock Gene in Mouse Cells. Proceedings of the National Academy of Sciences of the United States of America, 78, 7038-7042. http://dx.doi.org/10.1073/pnas.78.11.7038

[31] Sund, H. (1977) Pyridine Nucleotide-Dependent Dehydrogenases. Proceedings of the 2nd International Symposium, University of Konstanz, 28 March-1April 1977, FEBS Symposium, De Gruyter.

[32] Marco, R. (2006) The Scientific Roots of José A. Campos-Ortega, a German Neurobiologist Born in Spain. Developmental Dynamics, 235, 855-860. http://dx.doi.org/10.1002/dvdy.20700

[33] Wigler, M., Perucho, M., Kurts, D., Dana, S., Pellicer, A., Axel, R. and Silverstein, S. (1980) Transformation of Mammalian Cells with an Amplifiable Dominant-Acting Gene. Proceedings of the National Academy of Sciences of the United States of America, 77, 3567-3570. http://dx.doi.org/10.1073/pnas.77.6.3567

[34] Perucho, M., Hanahan, D., Lipsich, L. and Wigler, M. (1980) Isolation of the Chicken Thymidine Kinase Gene by Plasmid Rescue. Nature, 285, 207-210. http://dx.doi.org/10.1038/285207a0

[35] Perucho, M., Hanahan, D. and Wigler, M. (1980) Genetic and Physical Linkage of Exogenous Sequences in Transformed Cells. Cell, 22, 309-317. http://dx.doi.org/10.1016/0092-8674(80)90178-6

[36] Guerrero, I., Villasante, A., Corcés, V. and Pellicer, A. (1984) Activation of a c-K-Ras Oncogene by Somatic Mutation in Mouse Lymphomas Induced by Gamma Radiation. Science, 225, 1159-1162. http://dx.doi.org/10.1126/science.6474169

[37] Shimizu, K., Goldfarb, M., Perucho, M. and Wigler, M. (1983) Isolation and Preliminary Characterization of the Transforming Gene of a Human Neuroblastoma Cell Line. Proceedings of the National Academy of Sciences of the United States of America, 80, 383-387. http://dx.doi.org/10.1073/pnas.80.2.383

[38] Nakano, H., Yamamoto, F., Neville, C., Evans, D., Mizuno, T. and Perucho, M. (1984) Isolation of Transforming Sequences of Two Human Lung Carcinomas: Structural and Functional Analysis of the Activated c-K-Ras Oncogenes. Proceedings of the National Academy of Sciences of the United States of America, 81, 71-75. http://dx.doi.org/10.1073/pnas.81.1.71

[39] Winter, E., Yamamoto, F., Almoguera, C. and Perucho, M. (1985) A Method to Detect and Characterize Point Mutations in Transcribed Genes: Amplification and Overexpression of the Mutant c-Ki-Ras Allele in Human Tumor Cells. Proceedings of the National Academy of Sciences of the United States of America, 82, 7575-7579. http://dx.doi.org/10.1073/pnas.82.22.7575

[40] Barbacid, M., Troxler, D.H., Scohijck, E.M. and Aaronson, S.A. (1978) Analysis of Translational Products of Friend Strain of Spleen Focus-Forming Virus. Journal of Virology, 27, 826-830.

[41] Barbacid, M., Stephenson, J.R. and Aaronson, S.A. (1976) Gag Gene of Mammalian Type-C RNA Tumor Viruses. 
Nature, 262, 554-559. http://dx.doi.org/10.1038/262554a0

[42] Larraga, V. and Muñoz, E. (1975) Molecular-Organization in Bacterial Cell-Membranes. Specific Labelling and Topological Distribution of Glycoproteins and Proteins in Streptomyces-Albus Membranes. European Journal of Biochemistry, 54, 207-218. http://dx.doi.org/10.1111/j.1432-1033.1975.tb04130.x

[43] Barbacid, M., Robbins, K.C. and Aaronson, S.A. (1979) Wild Mouse RNA Tumor Viruses. A Nongenetically Transmitted Virus Group Closely Related to Exogenous Leukemia Viruses of Laboratory Mouse Strains. The Journal of Experimental Medicine, 149, 254-266. http://dx.doi.org/10.1084/jem.149.1.254

[44] Barbacid, M., Beemon, K. and Devare, S.G. (1980) Origin and Functional Properties of the Major Gene Product of the Snyder-Theilen Strain of Feline Sarcoma Virus. Proceedings of the National Academy of Sciences of the United States of America, 77, 5158-5162. http://dx.doi.org/10.1073/pnas.77.9.5158

[45] Barbacid, M. (1981) Cellular Transformation by Subgenomic Feline Sarcoma Virus DNA. Journal of Virology, 37, 518-523.

[46] Pulciani, S., Santos, E., Lauver, A.V., Long, L.K., Aaronson, S.A. and Barbacid, M. (1982) Oncogenes in Solid Human Tumours. Nature, 300, 539-542. http://dx.doi.org/10.1038/300539a0

[47] Reddy, E.P., Reynolds, R.K., Santos, E. and Barbacid, M. (1982) A Point Mutation Is Responsible for the Acquisition of Transforming Properties by the T24 Human Bladder Carcinoma Oncogene. Nature, 300, 149-152. http://dx.doi.org/10.1038/300149a0

[48] Sukumar, S., Notario, V., Martin-Zanca, D. and Barbacid, M. (1983) Induction of Mammary Carcinomas in Rats by Nitroso-Methylurea Involves Malignant Activation of H-Ras-1 Locus by Single Point Mutations. Nature, 306, 658-661. http://dx.doi.org/10.1038/306658a0

[49] Szybalska, E.H. and Szybalski, W. (1962) Genetics of Human Cell Lines, IV. DNA-Mediated Heritable Transformation of a Biochemical Trait. Proceedings of the National Academy of Sciences of the United States of America, 48, 2026-2034. http://dx.doi.org/10.1073/pnas.48.12.2026

[50] Pollack, R., Salas, J., Wang, R., Kusano, T. and Green, H. (1977) Human-Mouse Hybrid Cell Lines and Susceptibility to Species-Specific Viruses. Journal of Cellular Physiology, 77, 117-119. http://dx.doi.org/10.1002/jcp.1040770113

[51] Perucho, M., Salas, J. and Salas, M.L. (1977) Identification of Mammalian DNA-Binding Protein P8 as Glyceraldehyde3-Phosphate Dehydrogenase. European Journal of Biochemistry, 81, 557-562. http://dx.doi.org/10.1111/j.1432-1033.1977.tb11982.x

[52] Guerrero, I., Villasante, A., Corces, V. and Pellicer, A. (1985) Loss of the Normal N-Ras Allele in a Mouse Thymic Lymphoma Induced by a Chemical Carcinogen. Proceedings of the National Academy of Sciences of the United States of America, 82, 7810-7814. http://dx.doi.org/10.1073/pnas.82.23.7810

[53] Santos, E., Martin-Zanca, D., Reddy, E.P., Pierotti, M.A., Della Porta, G. and Barbacid, M. (1984) Malignant Activation of a K-Ras Oncogene in Lung Carcinoma but Not in Normal Tissue of the Same Patient. Science, 223, 661-664. http://dx.doi.org/10.1126/science.6695174 
Scientific Research Publishing (SCIRP) is one of the largest Open Access journal publishers. It is currently publishing more than 200 open access, online, peer-reviewed journals covering a wide range of academic disciplines. SCIRP serves the worldwide academic communities and contributes to the progress and application of science with its publication.

Other selected journals from SCIRP are listed as below. Submit your manuscript to us via either submit@scirp.org or Online Submission Portal.
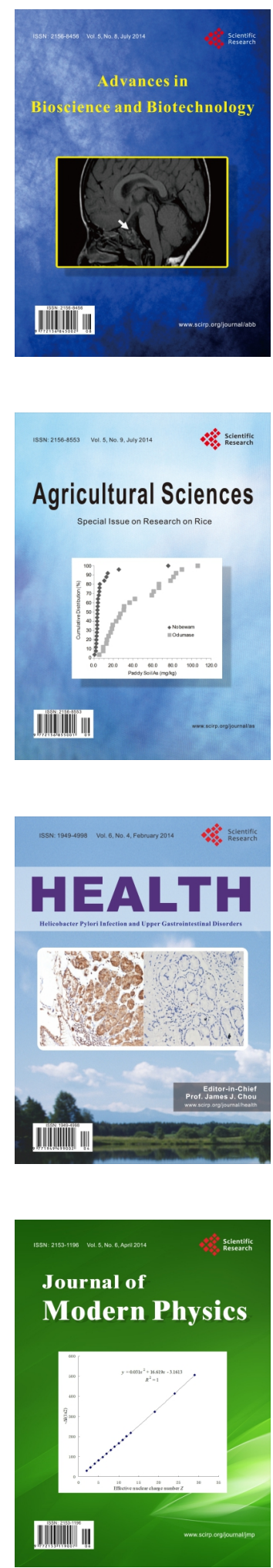
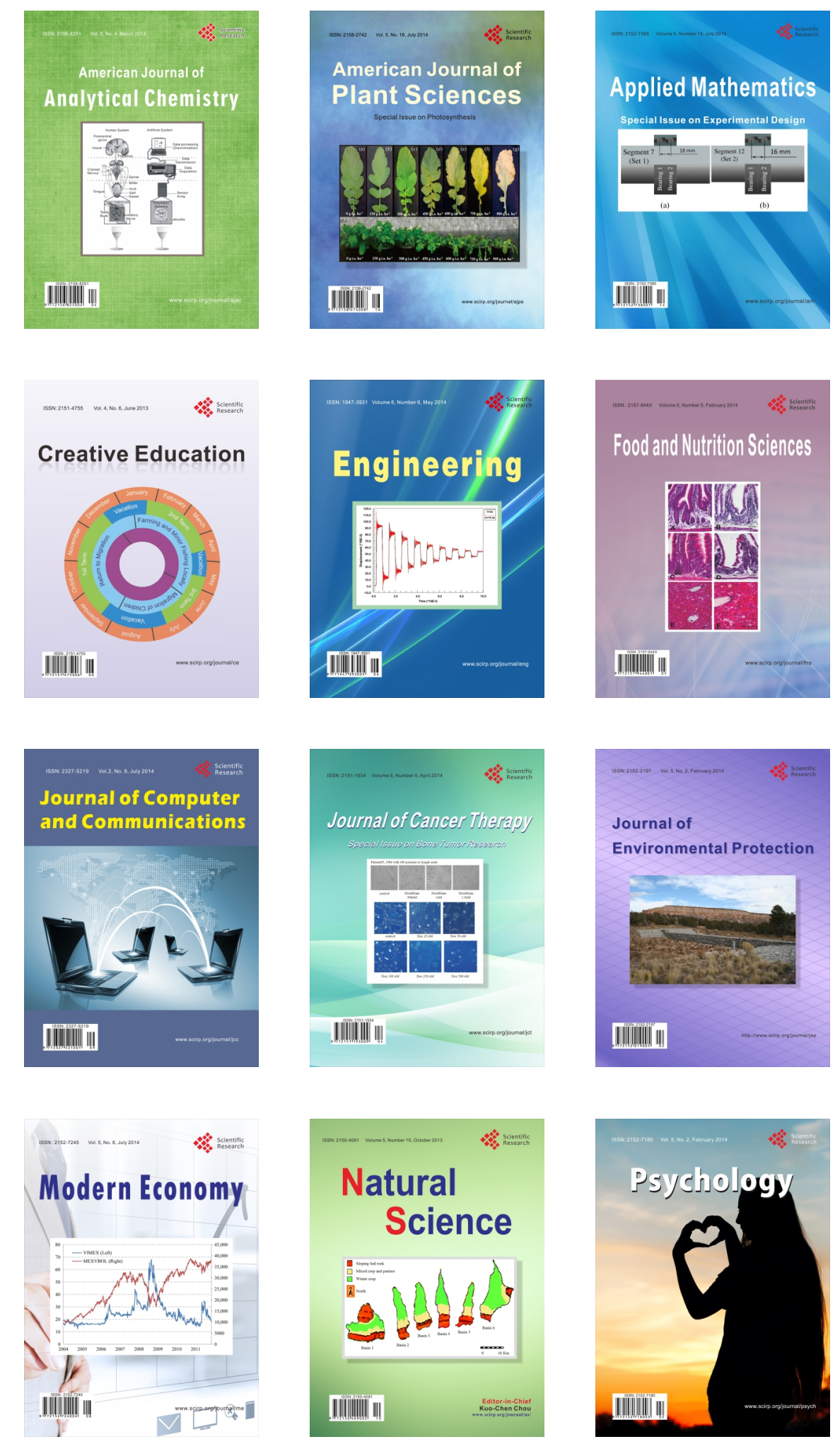